\title{
Результати лікування варикозної хвороби нижніх кінцівок, асоційованої з дисплазією сполучної тканини, з використанням ендовенозної лазерної коагуляціі
}

\author{
І. Я. Дзюбановський, А. М. Продан
}

Тернопільський державний медичний університет імені І. Я. Горбачевського МОЗ України

\section{Results of treatment of varicose disease of the lower extremities, associated with the connective tissue dysplasia, using endovenous laser coagulation}

\author{
I. Ya. Dzyubanovskyi, A. M. Prodan \\ Ternopil State Medical University named after I. Ya. Gorbachevskyi
}

Реферат

Мета. Клінічна оцінка впливу ендовенозної лазерної коагуляції (ЕВЛК) за різних режимів потужності в пацієнтів при дисплазії сполучної тканини (ДСТ) для визначення її меж для зменшення негативного впливу теплової енергії та покращення результатів лікування.

Матеріали і методи. У 51 (34,7\%) пацієнта з варикозною хворобою нижніх кінцівок і ознаками недиференційованої ДСТ (НДСТ) застосовано ЕВЛК потужністю 15 Вт та 10 Вт.

Результати. Встановлене достовірне переважання травматичних (термічних - болісні тяжі, парестезія, больовий синдром) і запальних (інфільтрати, тромбофлебіт, набряк м'яких тканин) ускладнень при використанні ЕВЛК потужністю 15 Вт. При зменшенні потужності ЕВЛК до 10 Вт лікування виявилося ефективним та безпечним.

Висновок. При виборі режиму потужності ЕВЛК слід мати на увазі наявність супутньої ДСТ для мінімізації частоти термічних ускладнень

Ключові слова: варикозна хвороба нижніх кінцівок; дисплазія сполучної тканини; ендовенозна лазерна коагуляція.

Abstract

Objective. Clinical estimation of impact of endovenous laser coagulation (EVLC) in various regimes of power in patients, suffering the connective tissue dysplasia (CTD) for determination of its borders for reduction of negative impact of thermal energy and improvement of the treatment results.

Materials and methods. In 51 (34.7\%) of patients, suffering varicose disease of the lower extremities and the signs of nondifferentiated CTD the EVLC with the $15 \mathrm{~W}$ and $10 \mathrm{~W}$ power were applied.

Results. There was established a trustworthy advantage of traumatic (thermal - painful strands, parestesy, the pain syndrome) and of inflammatory (infiltrates, thrombophlebitis, the soft tissues oedema) complications while the EVLC application with the $15 \mathrm{~W}$ power. While reduction of the EVLC power down to $10 \mathrm{~W}$ the treatment proved to be effective and secure.

Conclusion. While selecting the power regime in EVLC it is mandatory to take into account the presence of concomitant CTD for minimization of the thermal complications rate

Keywords: varicose disease of the lower extremities; dysplasia of connective tissue; endovenous laser coagulation.

Варикозна хвороба (ВХ) вен нижніх кінцівок (НК) суттево погіршує якість життя пацієнтів, починаючи з косметичних та естетичних дефектів на ранніх стадіях, та призводить до тяжкої інвалідизації при появі трофічних розладів [1]. Сьогодні цю проблему успішно вирішують хірургічним шляхом 3 використанням сучасних оперативних методів [2]. Проте значна частота післяопераційних ускладнень при застосуванні ендоваскулярних методів лікування [3-5] свідчить про відсутність диференційованого підходу до вибору хірургічної тактики лікування кожного пацієнта, оскільки при загальноприйнятому діагностичному обстеженні достатньою мірою не зважають на ступінь ураження венозної системи НК та його генез, зокрема за супутнього синдрому НДСТ [6 - 8]. При застосуванні ЕВЛК за «класичним» протоколом у деяких хворих виникає термічне ушкодження НК. Ці зміни певною мірою можуть бути зумовлені не діагностованим до операції зв'язком варикозного проце- су з ДСТ, а отже, браком необхідної інформації, що зменшує ефективність методу.

Мета дослідження - клінічне оцінювання впливу ЕВЛК за різних режимів потужності в пацієнтів 3 проявами НДСТ для визначення допустимих іiі меж з метою зменшення негативного впливу теплової енергії та покращення результатів лікування пацієнтів.

\section{Матеріали і методи дослідження}

Обстежені 147 пацієнтів, яких 3 приводу ВХНК лікували в хірургічному відділенні й рентгеноендоваскулярної та серцево-судинної хірургії Тернопільської міської лікарні № 2 в період з 2013 по 2017 р. Пацієнти розподілені на основі встановлених до операції маркерів НДСТ. у 96 (65,3\%) хворих (1-ша група) не виявлено критичної кількості ознак ДСТ (понад 6 стигм); у 51 (34,7\%) хворого (2-га група) - виявлені клініко-фенотипові, біохімічні та інструментальні (ультразвукові, морфологічні, мор- 


\begin{tabular}{|c|c|c|c|c|}
\hline \multirow{3}{*}{ Клас за СЕАР } & \multicolumn{4}{|c|}{ Кількість хворих у групах } \\
\hline & \multicolumn{2}{|c|}{$1-\breve{~}(n=96)$} & \multicolumn{2}{|c|}{$2-и ̆(n=51)$} \\
\hline & абс. & $\%$ & абс. & $\%$ \\
\hline C 2 & 51 & 53,1 & 20 & 39,2 \\
\hline C 3 & 22 & 22,9 & 10 & 19,6 \\
\hline C 4 & 14 & 14,6 & 8 & 15,7 \\
\hline C 5 & 9 & 9,4 & 7 & 13,7 \\
\hline C 6 & - & - & 6 & 11,8 \\
\hline
\end{tabular}

Таблиця 2. Методи хірургічного лікування пацієнтів з приводу ВХНК

\begin{tabular}{|c|c|c|c|c|}
\hline \multirow{3}{*}{$\begin{array}{c}\text { Метод оперативного } \\
\text { лікування }\end{array}$} & \multicolumn{4}{|c|}{ Кількість хворих в групах } \\
\hline & \multicolumn{2}{|c|}{ 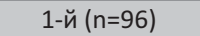 } & \multicolumn{2}{|c|}{$2-\breve{~}(n=51)$} \\
\hline & абс. & $\%$ & абс. & $\%$ \\
\hline KЕ, ТС, ЛПВ & - & - & 6 & 11,8 \\
\hline КЕ, ЕВЛК, СО, ЛПВ & 68 & 70,8 & 8 & 15,7 \\
\hline КЕ, ЕВЛК, КС, ЛПВ & 16 & 16,7 & 37 & 72,5 \\
\hline ЕВЛК (без КЕ), СО, ЛПВ & 12 & 12,5 & - & - \\
\hline \multicolumn{5}{|c|}{$\begin{array}{ll}\text { Примітка. } & \text { КЕ - кросектомія; СО - склерооблітерація; } \\
& \text { КС- короткий стрипінг; ТС-тотальний стрипінг; } \\
& \text { ЛПВ - лігування пронизних вен. }\end{array}$} \\
\hline
\end{tabular}

фометричні) прояви НДСТ різної тяжкості. Вік пацієнтів від 19 до 72 років, у середньому в 1-й групі - (43,94 \pm

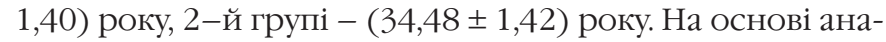
лізу та даних об'єктивного обстеження пацієнтів встановлений клас ВХНК за класифікацією СЕАР (табл. 1).

Методи хірургічного лікування пацієнтів обох груп наведені в табл. 2 .

Лазерну облітерацію проводили в безперервному режимі. Довжина хвилі лазера становила 1470 нм, тип світловода - радіальний, товщиною 600 мкм. Потужність лазерного випромінювання становила 10 і 15 Вт. Швидкість тракції світловода лазера до 5 мм/с - при потужності 15 Вт, не менше 5 мм/с - при потужності 10 Вт. Відповідно до використаного режиму ЕВЛК пацієнти 2-ї групи розподілені на дві підгрупи: 2.1 підгрупа - 17 (33,3\%) хворих, у яких потужність випромінювання становила 15 Вт; 2.2 підгрупа - 28 (54,9\%) хворих, у яких потужність 10 Вт. Не включені в дослідження 6 (11,8\%) пацієнтів через виконання в них «класичної» флебектомії.

Для оцінювання результатів хірургічного лікування пацієнтів оглядали за визначеним алгоритмом: обов'язковий огляд у 1-шу, на 3, 5, 7-му добу, через 1, 3, 6 міс та 1 рік після операції з визначенням клінічних змін та ускладнень; УЗД з оцінюванням надійності та ступеня облітерації підшкірних вен (після виконання ЕВЛК), стану НК після флебектомії; ступінь регресу клінічних проявів хронічної венозної недостатності (XBH) після операції (за шкалою VCSS), ступінь відновлення працездатності (за шкалою VDS), шкала сегментарності (VSDS), косметичний ефект втручання [9]; оцінку вираженості больового синдрому в ранньому післяопераційному періоді проводили за візуальною аналоговою шкалою (Visual Analogue Scale Pain Intensity Assessment) [10].

\section{Результати та іх обговорення}

Аналіз клінічних змін та ускладнень у ранньому післяопераційному періоді у групах хворих наведений у табл.3.
Клінічні зміни після використання ЕВЛК потужністю 10 Вт у підгрупі пацієнтів з проявами НДСТ свідчили про позитивний вплив зменшення потужності при збереженні ефективності методу.

Оцінюючи основні клінічні симптоми, ми встановили значне зменшення, а в деяких хворих - практично відсутність ознак надмірної термічної дії лазерного випромінювання. Найчастішими симптомами, що спостерігали після операції, були утворення незначно вираженого тяжа за ходом коагульованої вени та больовий синдром, вираженість якого порівняно з таким у підгрупі 2.1 значно менша $(\mathrm{p}<0,05)$.

У ранньому післяопераційному періоді (у 1-шу добу після операціі) вираженість больового синдрому в 1-й групі становила у середньому $(4,10 \pm 0,25)$ бала, в 2.1 підгрупі - (6,05 \pm 0,37) бала, в 2.2 підгрупі - $(4,27 \pm 0,41)$ бала.

За даними УЗД після ЕВЛК протягом періоду спостереження виявляли ознаки утворення асептичного тромбу з подалышою його організацією, хронічною оклюзією і поступовим заміщенням вени сполучнотканинним тяжем. На 7-му добу відзначали ехогенну неоднорідність просвіту вени з ехопозитивними включеннями різної щільності, просвіт вени не візуалізувався, спонтанний антеградний і стимульований кровотік відсутній. У підгрупі 2.1 період формування тяжа дещо більший внаслідок термічного пошкодження стінки вени та паравазальної клітковини. Виявляли ділянки розмитих контурів коагульованої вени, неоднорідність ехоструктури, ширший тяж, гіперехогенні включення в просвіті (тромби). Під час огляду через 1, 3 міс спостерігали позитивну динаміку - зменшення тяжкості запалення, зумовленого термічним впливом лазерного випромінювання, що збігалося з регресом клінічних змін у цій підгрупі.

Оцінка клінічної тяжкості до операції (VCSS) дорівнювала в $1-$ й групі - $(7,74 \pm 0,40)$ бала, анатомічний рахунок (VSDS - сегментарний рахунок рефлюксу) - (2,07 \pm $0,14)$ бала, фізичної активності (VDS) - $(1,05 \pm 0,10)$ бала. У середньому тяжкість захворювання (VSS) становила $(10,87 \pm 0,60)$ бала.

У пацієнтів 2-ї групи ці показники були більшими внаслідок переважно поширеного та поєднаного ураження вен та комбінованого рефлюксу практично на всій НК, встановленому за даними УЗД ангіосканування. Так, показник клінічної тяжкості до операції (VCSS) становив у підгрупі $2.1-(10,0 \pm 0,77)$ бала, у підгрупі $2.2-$ $(9,57 \pm 0,62)$ бала $(\mathrm{p}>0,05)$; анатомічний рахунок (VSDS) - відповідно $(3,43 \pm 0,26)$ та $(3,15 \pm 0,14)$ бала $(\mathrm{p}>0,05)$, фізичної активності (VDS) - (1,52 $\pm 0,11)$ і $(1,43 \pm 0,11)$ бала (p > 0,05); сумарна тяжкість захворювання (14,95 \pm $1,02)$ та $(14,15 \pm 0,88)$ бала, що достовірно більше показника в $1-$ й групі - $(10,87 \pm 0,60)$ бала $(\mathrm{p}<0,05)$.

Показовим $€$ аналіз динаміки основних симптомів $\mathrm{XBH}$, фізичної реабілітації, що входять до складу шкали загального клінічного рахунку (VCSS) в двох групах до і після оперативного лікування, що свідчило про ефективність використаного методу. У віддаленому післяопераційному періоді проведений повторний огляд 23 (23,9\%) пацієнтів 1-ї групи, 14 (66,7\%) - 2.1 підгрупи та 22 (73,3\%) - 2.2 підгрупи через 1, 3 і 6 міс після операції.

Швидке та виражене зменшення середнього показника тяжкості захворювання (VSS) в 4,2 раза - через 1 міс, у 


\begin{tabular}{|c|c|c|c|c|c|c|c|c|c|}
\hline \multirow{5}{*}{$\begin{array}{l}\text { Клінічні зміни та } \\
\text { ускладнення }\end{array}$} & \multicolumn{9}{|c|}{ Кількість спостережень в групах } \\
\hline & \multicolumn{3}{|c|}{$1-и ̆(n=96)$} & \multicolumn{6}{|c|}{$2-\breve{~}(n=51)$} \\
\hline & $\begin{array}{c}\mathrm{KE}, \mathrm{EB} Л \mathrm{~K}, \mathrm{CO} \\
(\mathrm{n}=68)\end{array}$ & $\begin{array}{c}\text { ЕВЛК, CO } \\
(n=12)\end{array}$ & $\begin{array}{c}\text { KE, ЕВЛК, KC } \\
(n=16)\end{array}$ & \multicolumn{4}{|c|}{$\begin{array}{c}\mathrm{KE}, \mathrm{EB} / \mathrm{K}, \mathrm{CO} \\
(\mathrm{n}=45)\end{array}$} & \multirow{2}{*}{\multicolumn{2}{|c|}{$\mathrm{KE}, \mathrm{TC}(\mathrm{n}=6)$}} \\
\hline & \multicolumn{3}{|c|}{15 Вт $(n=96)$} & \multicolumn{2}{|c|}{$15 \mathrm{BT}(\mathrm{n}=17)$} & \multicolumn{2}{|c|}{10 Bт $(n=28)$} & & \\
\hline & абс. & & $\%$ & абс. & $\%$ & абс. & $\%$ & абс. & $\%$ \\
\hline $\begin{array}{l}\text { Індурація по ходу } \\
\text { коагульованих вен } \\
\text { (тяж) }\end{array}$ & 9 & & 9,4 & 8 & 47,1 & 2 & 7,1 & - & - \\
\hline $\begin{array}{l}\text { Екхімози по ходу } \\
\text { вен }\end{array}$ & 14 & & 14,6 & 5 & 29,4 & 3 & 10,7 & - & - \\
\hline $\begin{array}{l}\text { Флебіт } \\
\text { коагульованих вен }\end{array}$ & 3 & & 3,1 & 7 & 41,2 & - & - & - & - \\
\hline $\begin{array}{l}\text { Гематоми за ходу } \\
\text { коагульованих вен }\end{array}$ & 5 & & 5,2 & 6 & 35,3 & 2 & 7,1 & 4 & 66,7 \\
\hline $\begin{array}{l}\text { Больовий синдром } \\
\text { у строки } 1 \text { - } 3 \text { доби }\end{array}$ & 25 & & 26,0 & 15 & 88,2 & 7 & 25,0 & 6 & 100 \\
\hline $\begin{array}{l}\text { Больовий синдром } \\
\text { пізніше ніж } 3 \text { доби }\end{array}$ & 10 & & 10,4 & 12 & 70,6 & 3 & 10,7 & 5 & 83,3 \\
\hline Парестезія & 7 & & 7,3 & 11 & 64,7 & 1 & 3,6 & 2 & 33,3 \\
\hline Опік шкіри & - & & - & 2 & 11,8 & - & - & - & - \\
\hline Набряк НК & 9 & & 9,4 & 5 & 29,4 & 2 & 7,1 & 1 & 16,7 \\
\hline Лімфорея & - & & - & - & - & & - & - & \\
\hline $\begin{array}{l}\text { Нагноєння } \\
\text { операційної рани }\end{array}$ & - & & - & - & - & & - & - & \\
\hline Інфільтрат & 3 & & 3,1 & 4 & 23,5 & - & - & 1 & 16,7 \\
\hline Гіперпігментація & 4 & & 4,2 & 6 & 35,3 & 2 & 7,1 & - & - \\
\hline
\end{tabular}

6 разів - через 3 міс та майже у 9 разів - через 6 міс $(\mathrm{p}<$ $0,05)$ у підгрупі 2.2 свідчило про високу ефективність обраного методу ЕВЛК із заданими зменшеними параметрами потужності лазерного випромінювання для лікування пацієнтів з ознаками НДСТ. Повільний регрес клінічних показників (у 2,32 раза - за перший місяць, у 3,84 раза - через 3 міс, у 4,7 раза - за 6 міс спостереження) у пацієнтів при ВХНК з НДСТ, у яких здійснювали коагуляцію за потужності 15 Вт, свідчив про наявність зв'язку між виявленими клінічними змінами та тяжкістю термічного ураження як в ранньому, так і віддаленому післяопераційному періоді, що погіршувало його перебіг і раннє відновлення працездатності та достовірно відрізнялося від результатів в інших групах $(\mathrm{p}<0,05)$.

Для оцінювання результатів лікування через 1 рік обстежені 11 (11,5\%) пацієнтів 1-ї групи, 9 (52,9\%) - 2.1 підгрупи, 10 (35,7\%) - 2.2 підгрупи. У групі 1 і підгрупі 2.2 відзначені практично однакові результати об'єктивного та інструментального дослідження, що свідчило про хороший клінічний та косметичний ефект. У підгрупі 2.1 результати ЕВЛК потужністю 15 Вт були достовірно гірші, що зумовлено термічними ускладненнями $(\mathrm{p}<0,05)$.

Косметичні результати операцій оцінювали через 12 Mic.

Незадовільних результатів лікування не було Відмінний результат досягнутий у 3 (27,3\%) пацієнтів 1-ї групи та 6 (37,5\%) - 2.2 підгрупи; хороший - відповідно у 7 (63,6\%) та 8 (50,0\%), що достовірно відрізнялось від такого у підгрупі 2.1 - у 3 (33,3\%) пацієнтів (р < 0,05); задовільний результат через наявність гіперпігментації, помірно щільного тяжа коагульованої вени внаслідок термічних опіків м'яких тканин відзначили 5 (55,6\%) пацієнтів 2.1 підгрупи.

\section{Висновки}

1. Відзначене достовірне переважання частоти травматичних (термічного - болючі тяжі, парестезія, больовий синдром) та запальних (інфільтрати, тромбофлебіт, набряк м'яких тканин) ускладнень у пацієнтів підгрупи 2.1 порівняно 3 такою в 1-й групі та підгрупі 2.2, у яких метод ЕВЛК у визначених параметрах був ефективний та безпечний при застосуванні, з хорошими післяопераційними результатами.

2. При виборі режиму потужності ЕВЛК слід обов'язково брати до уваги наявність супутньої ДСТ для мінімізації частоти післяопераційних ускладнень.

\section{References}

1. Rabe E, Guex JJ, Puskas A, Scuderi A, Fernandez Quesada F. The VCP Coordinators Epidemiology of chronic venous disorders in geographically diverse populations: results from the Vein Consult Program. Int Angiol. 2012;31(2):105-15.

2. Carradice D. Superficial venous insufficiency from the infernal to the endothermal. Ann Roy Coll Surg Engl. 2014;(96):5-10. doi: 10.1308/0 $03588414 X 13824511650498$.

3. Janne Do'thee B, Ghiorse D. Non-infected, non-haematic fluidcollections after endovenous laser ablation of the saphenous veins: a noteworthy complication. Phlebology. 2008;(23):47-9.

4. Mekako A, Chetter I. Cutaneous hyperpigmentation after endovenous laser therapy: a case report and literature review. Ann Vasc Surg. 2007 Sep;21(5):637-9. Epub 2007 May 17.

5. Wozniak W, Mlosek RK, Ciostek P. Complications and failure of endovenous laser ablation and radiofrequency ablation procedures in patients with lower extremity varicose veins in a 5-year follow-up. Vasc Endovasc Surg. 2016 Oct;50(7):475-83. doi:10.1177/1538574416671247

6. Zakharian EA. Morfologicheskie i fenotipicheskie markery displazii soedinitelnoi tkani u bolnykh s varikoznoi bolezniu ven nizhnikh konechnostei. Zaporozhskii meditcinskii zhurnal. 2013;(1):12-6. [In Russian]. 
7. Polovyi VP, Sydorchuk RI, Arseniuk VV, Railianu SI, Palianytsia AS, Karliichuk OO. Rol dysplazii spoluchnoi tkanyny v rozvytku poiednanoi khirurhichnoi patolohii. Klinichna ta eksperymentalna patolohiia. 2016;15(4):79-82. [In Ukrainian].

8. Svistunov AA, Tcarev OG, Masliakova GN. Klinicheskoe techenie varikoznoi bolezni s razlichnoi stepeniu vyrazhennosti displazii soedinitelnoi tkani. Saratovskii nauchno-meditcinskii zhurnal. 2009;5(2):59-61. [In Russian].

9. Passman MA, McLafferty RB, Lentz MF, Nagre SB, Iafrati MD, Bohannon WT, et al. Validation of Venous Clinical Severity Score (VCSS) with other venous severity assessment tools from the Ameri- can Venous Forum, National Venous Screening Program. J Vasc Surg. 2011;(54):2-9. doi: 10.1016 / j.jvs.2011.05.117. Epub 2011 okt. 1.

10. Hawker Gillian A, Mian S, Kendzerska T, French M. Measures of adult pain: Visual Analog Scale for pain (VAS Pain), Numeric Rating Scale for Pain (NRS Pain), McGill Pain Questionnaire (MPQ), Shortform McGill Pain Questionnaire (SFMPQ), Chronic Pain Grade Scale (CPGS), Short-form-36 Bodily Pain Scale (SF-36 BPS), and Measure of Intermittent and Constant Pain. Arthritis Care Res (Hoboken). 2011 Nov;63 Suppl 11:S240-52. doi: 10.1002/acr.20543. 